\title{
Congenital and maternal syphilis in the capital of Brazil
}

\author{
Carmen Lucia Muricy ${ }^{[1],[2]}$ and Vitor Laerte Pinto Júnior ${ }^{[1],[3]}$
}

[1]. Programa de Pós-Graduação em Medicina Tropical, Núcleo de Medicina Tropical, Universidade de Brasília, Brasília, Distrito Federal, Brasil. [2]. Ministério da Saúde, Brasília, Distrito Federal, Brasil. [3]. Diretoria Regional de Brasília da Fundação Oswaldo Cruz, Brasília, Distrito Federal, Brasil.

\begin{abstract}
Introduction: This study aimed to describe the epidemiology of congenital and maternal syphilis in the Brazilian Federal District in 2010. Methods: A retrospective descriptive study was conducted on the basis of the cases recorded in the System of Notifiable Disease Information. Results: The study population comprised 133 cases of congenital syphilis; of these, 116 $(52.6 \%)$ mothers received prenatal care, and $70(60.4 \%)$ were diagnosed with syphilis during pregnancy. Only 1 mother was adequately treated, and $100(75.2 \%)$ of the pregnant women's partners did not undergo treatment for syphilis. Conclusions: Although mothers attended prenatal care, not all were diagnosed during pregnancy or received adequate treatment for syphilis, as their partners did not undergo treatment for syphilis.
\end{abstract}

Keywords: Congenital syphilis. Vertical transmission. Prenatal care.

In developing nations, maternal syphilis and, consequently, congenital syphilis continue to be a public health problem, affecting approximately $10-15 \%$ of pregnant women ${ }^{(1)}$.

Congenital syphilis detection rates in Brazil, according to a series of studies conducted in 2008, 2009, and 2010, were $2.0,2.1$, and 2.4 cases $/ 1,000$ live births, respectively ${ }^{(2)}$.

In the Federal District (DF), which is one of the 27 units of the Federative Republic of Brazil, the number of cases and detection coefficients continued to increase between the years of $2007(\mathrm{n}=70$; detection coefficient $=1.6 / 1,000)$ and $2009(\mathrm{n}=117$; detection coefficient $=2.6 / 1,000)$, despite surveillance and disease control measures ${ }^{(3)}$.

The aim of this study was to describe the epidemiological characteristics of congenital and maternal syphilis cases diagnosed in the DF in 2010.

In this retrospective, observational study, data from 137 of children and their mothers with syphilis were collected from the System of Notifiable Disease Information of the Federal District (Sistema de Informação de Agravos de Notificação/ Distrito Federal - SINAN/DF) and the Live Birth Information System (Sistema de Informações de Nascidos Vivos - SINASC) between October 2013 and March 2014. The study area is located in the Midwestern region of Brazil that has an area of $5.779,999 \mathrm{~km}^{2}$, a demographic density of 444.07 individuals per

\footnotetext{
Corresponding author: Dra. Carmen Lucia Muricy. Campus Universitário Darcy Ribeiro s/n, Asa Norte, 70904-970 Brasília, Distrito Federal, Brasil. Phone: 5561 3315-9134

e-mail: clucia.muricy@gmail.com ; vitorlaerte@gmail.com

Received 20 July 2014

Accepted 29 October 2014
}

$\mathrm{km}^{2}$, and a population of $2,570,160^{(4)}$ inhabitants. The Federal District has 15 Regional Health Units and 106 establishments of Public Health ${ }^{(5)}$.

Collected variables included the federated unit of residence, child's sex, clinical manifestations of syphilis in newborns (jaundice, anemia, splenomegaly, osteochondritis, mucusbloody rhinitis, hepatomegaly, skin lesions, and pseudoparalysis), age, race, and diagnostic features of mother and child; treatment information (adequate, inadequate) for the mother, child, and partner; mother's occupation and educational level; and prenatal care. The neonatal treatment was evaluated by comparing the regimen registered in the SINAN/DF to the recommended regimen for congenital syphilis from the Ministry of Health of Brazil (MoH). For this analysis, stillbirths, abortions, and deaths were excluded, representing 119 neonates. Age was calculated in days by subtracting the date of the neonate from the date of diagnosis. Stillbirths and deaths were also excluded for Nontreponemal tests analysis, totalizing 124 cases.

To calculate the congenital syphilis detection rate among infants under 1 year of age in the DF, the following formula was used $^{(2)}$ : number of children less than 1 year of age diagnosed with congenital syphilis while living in the DF and recorded in the SINAN/DF in 2010/number of live births registered in the SINASC in 2010 while living in the DF $\times 1,000$. The coefficient of specific mortality from congenital syphilis was calculated using the following formula ${ }^{(2)}$ : number of deaths and stillbirths due to congenital syphilis registered in the SINAN/DF in 2010/number of live births registered in the SINASC in 2010 while living in the DF $\times 1,000$. The software package Epi Info TM 7.1 .5 (https://www.cdc.gov/epiinfo/html/ downloads.htm) was used for data processing and analysis, and data tables were constructed in Microsoft ${ }^{\circledR}$ Excel 2010 (Microsoft Corp, Redmond, WA, USA). 
A total of 137 children with congenital syphilis were reported in 2010; 4 of these patients had inconsistents records, and they were excluded, resulting in 133 children. The congenital syphilis detection rate among DF residents was 2.0/1,000 live births, and the coefficient of specific mortality from congenital syphilis was 0.1 deaths $/ 1,000$ live births.

Characteristics of the cases with congenital syphilis, including gender, skin color, age, state and area of residence, diagnostic test results are described in Table 1. Of the 133 cases, $84.9 \%(\mathrm{n}=113)$ were reported as live births, $3.8 \%(\mathrm{n}=5)$ as stillbirths, $3.8 \%(\mathrm{n}=5)$ as deaths, $2.3 \%(\mathrm{n}=3)$ as deaths specifically from congenital syphilis, and $3 \%(n=4)$ as abortions. The age (average \pm standard deviation) at diagnosis was $1.72 \pm 12.9$ days (range, 0-148 days), and newborns aged $<2$ days had the highest incidence $(87.3 \%, \mathrm{n}=116)$. Of the patients, $9 \%(n=12)$ exhibited clinical symptoms (jaundice, $3 \%, n=4$; anemia, $3 \%, \mathrm{n}=1$; and hepatomegaly, $3 \%, \mathrm{n}=1$ ). Nontreponemal tests were used to analyze peripheral blood samples from 106 $(79.7 \%, \mathrm{n}=124)$ children, with $63 \%(\mathrm{n}=78)$ reacting positively. Treatment was administered to 119 children, and $79.1 \%$ $(\mathrm{n}=87)$ were treated according to the $\mathrm{MoH}$ recommendations.

Characteristics of the maternal syphilis cases, including sex, skin color, age, diagnosis, and treatment are shown in Table 2. Of the 133 mothers of children with congenital syphilis, the highest rates (per 1,000 live births) were observed in mothers who were blackskinned (11.3/1,000 live births) or $\geq 40$ years old (4.0/1,000 live births). Most of the mothers had less than 9 years of education $(28.6 \%, \mathrm{n}=38)$, and the majority $(54.9 \%, \mathrm{n}=73)$ were homemakers. Prenatal consultations occurred in $87.2 \%$ $(\mathrm{n}=116)$ of the mothers, and $52.6 \%(\mathrm{n}=70)$ received confirmed diagnoses in the prenatal period. Another $12.8 \%(\mathrm{n}=17)$ did not undergo diagnostic tests, or the information was ignored even if they had undergone prenatal consultations. Treatment was inadequate for $88 \%$ of the mothers $(\mathrm{n}=117)$, and $75.2 \%(\mathrm{n}=100)$ of their partners had not received treatment.

The coefficient of specific mortality from congenital syphilis, which was lower in the DF than in other states in Brazil $^{(2)}$, might suggest underreporting.

Similar to other studies, child and maternal factors that are considered to increase the risk and vulnerability for congenital syphilis, such as black or brown skin color, low socioeconomic status, and maternal age between 20 and 30 years ${ }^{(6)}$, were observed in the present study ${ }^{(6)(7)(8)}$. Greater efforts should be undertaken to minimize inequalities for these vulnerable populations through strategies that enable greater access to health services.

Clinical manifestations in newborns are usually delayed, potentially occurring months or years $\operatorname{later}^{(9)}$. The high frequency of asymptomatic cases at birth in the present study supports the use of a surveillance system to identify more cases based on laboratory results. Furthermore, not all of the cases that were identified were treated in accordance with the $\mathrm{MoH}$ recommendations for the treatment of newborns with congenital syphilis ${ }^{(1)}$. The therapeutic regimens for newborns depend on the clinical, laboratory, and radiographic findings and range from a single application to up to 10 daily doses of penicillin ${ }^{(1)(8)}$.
TABLE 1 - Characteristics of congenital syphilis cases $(n=133)$ in the Federal District, Brazil, 2010.

\begin{tabular}{|c|c|c|}
\hline Variable & Number & Percentage \\
\hline \multicolumn{3}{|l|}{ Sex } \\
\hline male & 72 & 54.1 \\
\hline female & 56 & 42.1 \\
\hline unavailable & 5 & 3.8 \\
\hline \multicolumn{3}{|l|}{ Skin color } \\
\hline brown & 55 & 41.4 \\
\hline white & 12 & 9.0 \\
\hline black & 1 & 0.7 \\
\hline unavailable & 65 & 48.9 \\
\hline \multicolumn{3}{|l|}{ Age at diagnosis (days) } \\
\hline$<2$ & 116 & 87.3 \\
\hline $2-3$ & 11 & 8.3 \\
\hline $4-5$ & 2 & 1.5 \\
\hline $6-10$ & 1 & 0.7 \\
\hline$>10$ & 3 & 2.2 \\
\hline \multicolumn{3}{|l|}{ State of residence } \\
\hline Federal District & 88 & 66.2 \\
\hline Goiás & 42 & 31.6 \\
\hline Minas Gerais & 2 & 1.5 \\
\hline Maranhão & 1 & 0.7 \\
\hline \multicolumn{3}{|l|}{ Area of residence } \\
\hline urban & 113 & 84.9 \\
\hline rural & 9 & 6.8 \\
\hline peri-urban & 9 & 6.8 \\
\hline unavailable & 2 & 1.5 \\
\hline \multicolumn{3}{|c|}{ Blood nontreponemal test results } \\
\hline$<1: 4$ & 41 & 30.8 \\
\hline$\geq 1: 4$ & 37 & 27.8 \\
\hline non-reactive & 28 & 21.1 \\
\hline untested & 20 & 15.0 \\
\hline not informed & 7 & 5.3 \\
\hline \multicolumn{3}{|c|}{ CSF nontreponemal test results } \\
\hline reactive & 3 & 2.3 \\
\hline non-reactive & 50 & 37.5 \\
\hline untested & 53 & 40.0 \\
\hline not informed & 27 & 20.2 \\
\hline \multicolumn{3}{|l|}{ CSF abnormalities } \\
\hline yes & 5 & 3.8 \\
\hline no & 50 & 37.6 \\
\hline not evaluated & 52 & 39.1 \\
\hline not informed & 26 & 19.5 \\
\hline \multicolumn{3}{|c|}{ Long bone radiograph abnormalities } \\
\hline yes & 3 & 2.3 \\
\hline no & 70 & 52.6 \\
\hline not evaluated & 28 & 21.1 \\
\hline not informed & 32 & 24.0 \\
\hline \multicolumn{3}{|l|}{ Treatment $(n=119)$} \\
\hline adequately treated & 87 & 79.1 \\
\hline inadequately treated & 21 & 11.7 \\
\hline other treatment regimen & 14 & 11.8 \\
\hline untreated or unavailable & 11 & 9.2 \\
\hline
\end{tabular}

CSF: cerebrospinal fluid. 
TABLE 2 - Characteristics of maternal syphilis cases $(n=133)$ in the Federal District, Brazil, 2010.

\begin{tabular}{|c|c|c|}
\hline \multirow[b]{2}{*}{ Variable } & \multicolumn{2}{|c|}{ Rates per 1,000 live births } \\
\hline & $\mathrm{n}$ & $\%$ \\
\hline \multicolumn{3}{|l|}{ Skin color } \\
\hline brown & 88 & 3.7 \\
\hline white & 17 & 1.6 \\
\hline black & 4 & 11.3 \\
\hline not informed & 24 & 2.5 \\
\hline \multicolumn{3}{|l|}{ Age (years; $\mathrm{n}=128$ ) } \\
\hline$<20$ & 14 & 2.3 \\
\hline $20-29$ & 71 & 3.2 \\
\hline $30-39$ & 38 & 2.6 \\
\hline$\geq 40$ & 5 & 4.0 \\
\hline \multicolumn{3}{|l|}{ Education level (years) } \\
\hline none & 2 & 10.5 \\
\hline$<9$ & 38 & 28.6 \\
\hline $9-11$ & 24 & 18.1 \\
\hline 12 & 22 & 16.5 \\
\hline$\geq 13$ & 2 & 1.5 \\
\hline unavailable & 45 & 33.8 \\
\hline \multicolumn{3}{|l|}{ Occupation } \\
\hline homemaker & 73 & 54.9 \\
\hline other & 29 & 21.8 \\
\hline unavailable & 31 & 23.3 \\
\hline \multicolumn{3}{|l|}{ Prenatal care } \\
\hline yes & 116 & 87.2 \\
\hline no & 15 & 11.2 \\
\hline not informed & 2 & 1.5 \\
\hline \multicolumn{3}{|l|}{ Diagnosis at pregnancy } \\
\hline yes & 70 & 52.6 \\
\hline no & 47 & 35.4 \\
\hline unavailable & 16 & 12.0 \\
\hline \multicolumn{3}{|c|}{ Nontreponemal test results } \\
\hline$<1: 4$ & 53 & 39.8 \\
\hline$\geq 1: 4$ & 72 & 54.1 \\
\hline non-reactive & 2 & 1.5 \\
\hline untested & 3 & 2.3 \\
\hline unavailable & 3 & 2.3 \\
\hline \multicolumn{3}{|l|}{ Treponemal test results } \\
\hline reactive & 49 & 36.8 \\
\hline non-reactive & 2 & 1.5 \\
\hline untested & 62 & 46.6 \\
\hline unavailable & 20 & 15.1 \\
\hline \multicolumn{3}{|l|}{ Treatment } \\
\hline adequately treated & 1 & 0.7 \\
\hline inadequately treated & 117 & 88.0 \\
\hline unavailable & 15 & 11.3 \\
\hline \multicolumn{3}{|l|}{ Treatment of partner } \\
\hline yes & 10 & 7.5 \\
\hline no & 100 & 75.2 \\
\hline unavailable & 23 & 17.3 \\
\hline
\end{tabular}

The $\mathrm{MoH}$ recommends a minimum of six prenatal care consultations ${ }^{(10)}$. In the present study, prenatal assistance was provided to most of the mothers, at a similar frequency to other studies ${ }^{(6)}{ }^{(7)}$. However, this fact did not ensure early maternal diagnosis, ensure adequate treatment of the pregnant women and their partners, or prevent abortions, deaths, and stillbirths caused by congenital syphilis. The incidence of syphilis is considered an important indicator of the quality and accessibility of prenatal care ${ }^{(9)(10)(11)}$

Several studies have examined factors affecting the quality of prenatal assistance ${ }^{(9)(12)(13)}$ like access of health care service. These factors should be monitored, with appropriate interventions to prevent congenital syphilis.

Early maternal diagnosis remains the most effective strategy to prevent congenital syphilis ${ }^{(14)}$, because transplacental transmission of Treponema pallidum can be prevented more effectively. Serological tests remain the method of choice for maternal diagnosis ${ }^{(2)(10)}$, and prenatal visits provide the perfect opportunity to conduct these tests. We observed a high proportion of positive nontreponemal tests during delivery, which suggests that the health care system in the $\mathrm{DF}$ is following the recommendation to perform rapid tests for maternal syphilis during labor. Nevertheless, it is necessary to improve the system for syphilis diagnosis during prenatal care for pregnant women and their sexual partners. Treatment that begins at the end of pregnancy doesn't allow enough time to cease treatment in the required time to prevent vertical transmission to the newborn, fetal death, and prematurity ${ }^{(15)}$.

In addition, the proportion of inadequately treated mothers was higher in the present study than in previous studies ${ }^{(6)(14)}$, and more than $90 \%$ of the partners in our study were inadequately treated, untreated, or the information was ignored. When partners are left untreated or are inadequately treated, the risk of vertical transmission increases as a consequence of the reexposure of pregnant women to the infectious agent ${ }^{(15)}$. In our country, the partner's visit to the Health Unit depends on the pregnant woman; therefore, it is necessary for the mother to be properly educated regarding the importance of treatment. As the mothers were also inadequately treated, it is assumed that the information provided and prenatal approach were insufficient to sensitize the mothers, which could hardly be expected to sensitize their partners. A more active approach is expected from health services in the education of partners because relying exclusively on one member of the couple can undermine prevention strategies.

Limitations of the study include its descriptive design and the lack of comparison groups; therefore, analysis of potential causal relationships between the risk factors and outcomes could not be conducted. It is also possible that cases are underreported to the surveillance system. Restricting the sample to the DF also limits the ability to generalize the results.

Efforts must be undertaken by public health authorities to improve the quality of prenatal care, including the allocation of sufficient human resources and investment in training and continuing education for the counseling of pregnant women and their partners. The infrastructure and service organizations should also be reassessed. Several sectors are responsible for 
prenatal care, requiring joint discussion of strategies by these health and organized societies, or the aim to eliminate congenital syphilis will not be achieved.

\section{Ethical considerations}

This study was approved by the Ethics Committee of the Research and Education Foundation in the Health Sciences, in accordance with the Declaration of Helsinki.

\section{ACKNOWLEDGMENTS}

The author wishes to thank Dr. Ligia Passion, Director of the Epidemiological Surveillance State Department of Health of the DF, for granting permission to develop the study and her team for their cooperation in providing the data, with special attention to Leidjany Paz.

\section{CONFLICT OF INTEREST}

The authors declare that there is no conflict of interest.

\section{REFERENCES}

1. Ministério da Saúde. Secretaria de Vigilância em Saúde. Programa Nacional de DST/AIDS. Diretrizes para controle da sífilis congênita: manual de bolso. $2^{\text {nd }}$. ed. Brasília: Ministério da Saúde; 2006.

2. Ministério da Saúde, Secretaria de Vigilância em Saúde. Boletim Epidemiológico - AIDS e DST. Brasília: Ministério da Saúde; 2012.

3. Secretaria de Estado de Saúde do Distrito Federal. Diretrizes para redução da transmissão vertical do HIV e Sífilis no Distrito Federal. Brasília: Fepecs; 2009.

4. Instituto Brasileiro de Geografia e Estatística (IBGE). Sinopse do Censo Demográfico 2010 - Distrito Federal (Internet). IBGE; 2010. Cited 2012 April 10. Available at: http://www.censo2010.ibge.gov. $\mathrm{br} /$ sinopse/index.php? $\mathrm{uf}=53 \&$ dados $=0$
5. Secretaria de Estado de Saúde do Distrito Federal. Hospitais e Regionais (Internet). Cited 2013 Jun 04. Available at: http://www. saude.df.gov.br/sobre-a-secretaria/hospitais-e-regionais.html

6. Melo NGDO, Melo Filho DA, Ferreira LOC. Diferenciais intraurbanos de sífilis congênita no Recife, Pernambuco, Brasil (2004-2006). Epidemiol Serv Saude 2011; 20:213-222.

7. Holanda MTCG, Barreto MA, Machado RMM, Pereira RC. Perfil epidemiológico da sífilis congênita no Município do Natal, Rio Grande do Norte - 2004 a 2007. Epidemiol Serv Saude 2011; 20:203-212.

8. Magalhães DMS, Kawaguchi IAL, Dias A, Calderon IMP. Sífilis materna e congênita: ainda um desafio. Cad Saude Publica 2013; 29:1109-1120.

9. Centers for Disease Control and Prevention (CDC). Congenital syphilis: United States, 2003-2008 (Internet). MMWR Morb Mortal Wkly Rep 2010; 59:413-417. Cited 2014 Available at: http:// www.cdc.gov/std/stats10/syphilis.htm.

10. Ministério da Saúde. Portaria $\mathrm{n}^{\mathrm{o}} 1.459$, de 24 de junho de 2011. Institui, no âmbito do Sistema Único de Saúde - SUS - a Rede Cegonha. Portaria consolidada da Rede Cegonha. Diário Oficial da República Federativa do Brasil, 2011 jun; Seção 1, p. 109. Correção na portaria $\mathrm{n}^{0} 1.459$, de 24 de junho de 2011, publicada no DOU de 1 jul 2011, Seção 1, p. 61. Brasília: Ministério da Saúde; 2011.

11. Ministério da Saúde. Secretaria de Vigilância em Saúde. Programa Nacional de DST/AIDS. Plano Operacional para Redução da Transmissão Vertical do HIV e da Sífilis. Brasília: Ministério da Saúde; 2007.

12. Amaral E. Sífilis na gravidez e óbito fetal: de volta para o futuro. Internet. Rev Bras Ginecol Obstet 2012; 34:52-55.

13. Saraceni V, Miranda AE. Relação entre a cobertura da Estratégia Saúde da Família e o diagnóstico de sífilis na gestação e sífilis congênita. Cad Saude Publica 2012; 28:490-496.

14. Donalísio MR, Freire JB, Mendes ET. Investigação da sífilis congênita na microrregião de Sumaré, Estado de São Paulo, Brasil - desvelando a fragilidade do cuidado à mulher gestante e ao recém-nascido. Epidemiol Serv Saude 2007; 16:165-173.

15. Miranda AE, Rose Filho E, Trindade CR, Gouvêa GM, Costa DM, Oliveira TG, et al. Prevalência de sífilis e HIV utilizando testes rápidos em parturientes atendidas nas maternidades públicas de Vitória, Estado do Espírito Santo. Rev Soc Bras Med Trop 2009; 42:386-391. 